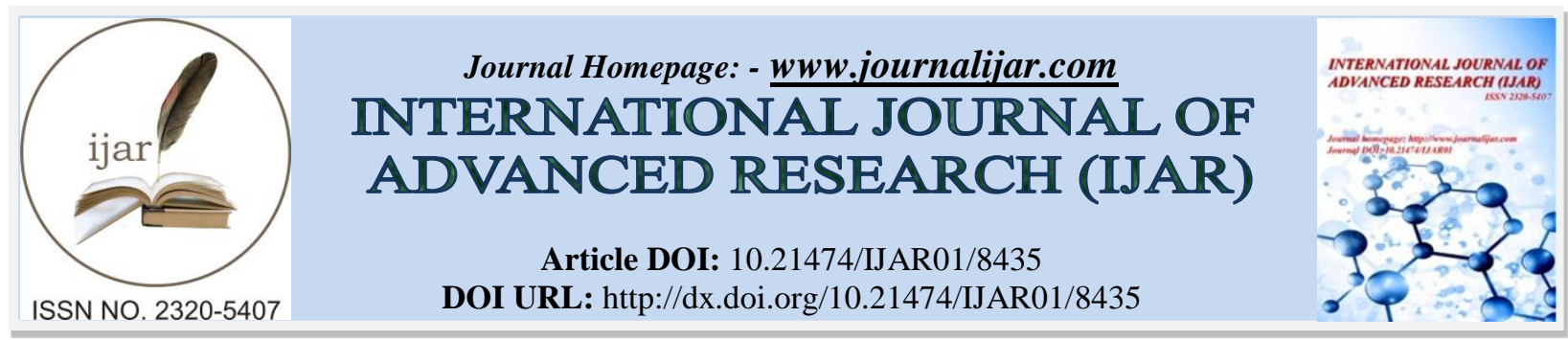

RESEARCH ARTICLE

\title{
THE RELATIONSHIP BETWEEN PRINCIPAL'S LEADERSHIP AND IMPLEMENTATION OF INSTITUTIONAL STRATEGIC PLANNING IN PUBLIC SECONDARY SCHOOLS IN ELDORET WEST SUB COUNTY, KENYA.
}

Everline nyaboke kamemba, lelan joseph and tuitoek j. F. K.

Department of Education Administration and Management,Moi University, Eldoret, Kenya.

\section{Manuscript Info}

Manuscript History

Received: 20 November 2018

Final Accepted: 22 December 2018

Published: January 2019

Key words:-

Relationship, Principals, Leadership, Strategic plans.

\section{Abstract}

The purpose of the study was to investigate relationship between principals' leadership and implementation of institutional strategic planning in Eldoret West sub-county public secondary schools; Kenya. Many schools have come up with strategic plans as directed by the Ministry of Education. There are those who have successfully accomplished their set objective but some have failed to. The current study adopted a descriptive survey design using mixed methodology. The study targeted 53 principals and 724 teachers. Krecjie and Morgan determination formula was used to obtain 276 teachers and 166 principals. The sampling procedures which were used in this research included, stratified, simple random sampling and purposive sampling techniques. Questionnaires were used to collect quantitative data from teachers while interviews were used to collect qualitative information from the principals. The validity of the research instruments was determined through expert judgment while reliability was obtained through piloting and use of Croncbach Alpha where a correlation coefficient of 0.79 was obtained on teachers' questionnaire. Qualitative data was analyzed through the use of frequencies and percentages and inferential statistics while qualitative data was thematically analyzed. The study found out a significant positive relationship between leadership $r=0.559$ ) and implementation of strategic plans and recommended that there is need for secondary school leadership to have the competencies required for effective implementation of strategic plans. These competencies include idealized characteristics, inspirational motivation, intellectual stimulation and individualized consideration. In addition, the study further recommends that there is need for budgeting of available resources.

Copy Right, IJAR, 2018,. All rights reserved.

\section{Introduction:-}

According to Winter (2003) and Blackerby (1993), strategic planning originated from warfare. The word strategy originates from Greek word strategies (a combination of stratus, army and a gain to conduct). The Greek term referred to the civil -military officials elected by the citizens of Athens to assume leadership during times of war. The strategies were expected to prepare and implement overall top-level plans in order to achieve the long-term goal

Corresponding Author:-Everline nyaboke kamemba.

Address:-Department of Education Administration and Management,Moi University, Eldoret, Kenya. 
of winning the war through battles, negotiation or any other means available, according to the changing situations. They were not directly in charge of daily short-term generations of managing troops to win specific battles, which was the responsibility of the lower ranking officers. This was (and still is) referred to as tactics, derived from the Greek word tactica, which means disposing and maneuvering forces in combat (from the verb tassein which means to arrange). From its military roots, strategic planning has at least two essential characteristics: To think big, by taking into consideration all possible options and paying due attention to changing the environment; and to focus on a clear long-term goal to be achieved.

Leithwood \&, Jantzi (2006) observes that strategic planning positively affects institutions' performance, or more specifically, the amount of strategic planning an institution conducts positively affects its general performance. An effective strategic plan implementation process involves devising of a well-crafted mission and objectives statement, environmental scanning, strategy formulation, strategy implementation and strategy evaluation and control (Ralph, 2008). The principal as a chief executive plays a critical role in this engagement. The principal is required to come up with plan strategies which are geared towards incorporating all stakeholders in the school.

A number of studies have identified strategic planning as a tool to guide schools' improvement initiatives in the future (Fullan 2004; Steyn \& Wolhuter 2010; Quong \& Walker 2010). For example, Steyn \& Wolhuter state that strategic planning helps in a school's self-study and evaluation, whereby areas of strengths and future challenges are identified and planned for. Eacott (2011), on the other hand, affirms that strategic planning can improve school community relationships, since it is a useful tool for communication across traditional boundaries in the school. In a nutshell, strategic planning sets the courses and directions for all development and growth within the school. This is because a strategic plan is the schools' avowal to the community of its goals, values and intents for achievements in the next five to ten years.

Kenya has a mandate of ensuring that the sustainable development Goals and Vision 2030 are achieved. This calls for the education sector to lay down targeted strategies. In a move to meet these demands, the government has tasked schools across the country to come up with appropriate targeted strategic plans. In theory, any school that formulates and implements a strategic plan derives a bundle of benefits such as: a base upon which progress can be measured, strong functional teams in managements with new ideas, which can steer the school to greater height of excellence and lastly consistency in financial kitties for development. These outcomes have been shown by Alde Hayyat et al 2011), Ngware et al (2006) among other authors.

Despite the evident benefits of Strategic planning availability and subsequent implementation, Ngware (2006) demonstrates that most schools fail to achieve their goals and objectives, and this reflects through academic performance and stalled school projects. Schools in Kenya continue to struggle with indiscipline cases, riots, strikes evidenced in recent burning of schools and funding challenges to implement their strategic plans. The funding challenge is major given the Kenya government recent policy on Free Secondary School Education. Through informal interviews between the researcher and education stakeholders in Uasin Gishu County, there is a gap in implementation of strategic plans in Eldoret West Sub County Public secondary schools. Therefore, the current research investigated the relationship between principals' leadership competencies and strategic plan implementation in secondary schools.

\section{Literature Review}

Leadership is seen as a dynamic-energetic process which consists of an interconnected and interdependent set of roles to energize a group toward the realization of goals. Leadership role pertains to the observable way of performing leadership. According to Graetz (2010) and Mattis (2011), one of the roles of leadership involves providing strategic direction. Leadership and specifically strategic leadership has been identified as one of the key drivers of effective strategy implementation. Thompson, Strickland and Gamble (2013) are emphatic that the leadership's role is all important because its agenda for action and conclusion about how hard or fast to push for change are decisive in shaping the character of the implementation and moving the process along. In the words of Chapman (2012), leadership is the common thread which runs through the entire process of translating strategy into results and is the key to engaging the hearts and minds of people.

According to Richard, (2010) the primary key to successful strategy execution is leadership. Yang, 2008 referred the highest management team in an organization as senior leader who included the organizations presidents, stakeholders, executive and senior level managers. The board is one of the key subjects in implementation of 
strategies as per Schmidt and Braurer (2006) findings. In addition, Davies \& Davies (2010) pointed out that the participation and the intervention among the highest level of management in an organization, promotes greater commitment levels in implementation of a firm's vision and strategies which intern promotes success in the implementation of a firms selected strategy.

Research points out that running a school is challenging, stressful, difficult and time-consuming (Leithwood \& Jantzi 2005; Levine 2005). It appears that most of the school leader's time is spent responding to government requirements and less on educational leadership (Onguko et al. 2008). This often limits the principals' capacity to design strategies for school improvement (ibid). However, with the current competitive and demanding educational climate, principals cannot neglect to pay attention to accountability requirements of parents and the government. Most governments, the Kenyan included, have therefore established policies that require schools to undertake thoughtful, comprehensive strategic planning aimed at setting key strategies for sustainable improvement and determination of resource priorities (UNESCO 2010). Nevertheless, strategic planning goes beyond a school simply demonstrating that it complies by developing a strategic plan. It should be a declaration of a school's dedication to ongoing improvement.

Davis and Allison (2003) argue that, because of increasing external demands and uncertainty of events, school leadership has to be future oriented and strategically driven. They identified three characteristics of a future of the school community which is committed; an ability to scan the environment for future trends and directions and to adapt or work with them to help develop the school 's internal purpose; and the capacity to manage the change process. Jones (2012) highlights leadership as one of the seven keys to a successful strategic plan and asserts that the only way a leader is going to translate vision into reality is to anchor, implement and execute the vision through a variety of policies, procedures and systems that will willingly bring in people and empower them to implement the vision.

Omboi (2011) carried out an analysis of the factors influencing the implementation of strategic plans in selected schools in Meru South District, Kenya and focused on managerial behaviour, institutional policies, resources allocation, reward and incentive influence on implementation of strategic plans. The study findings pointed out that the strategic thinking of the school managers and the extrinsic motivation of the teachers contributed largely to the extent to which the strategies were implemented. Most of the strategic plans are kept in the office only to be made available to external school inspectors (Omboi, 2011).

According to Steven (2008) schools are being encouraged to develop 3 or 5 years strategic plan to define intended strategic course of actions. Shivach (2007) points out that secondary school head teachers are charged with the responsibility of managing schools on day to day basis and their work to ensure that educational aims are achieved. They occupy a positive leadership as they lead their team of teachers, students, non- teaching staff and parents towards achievement of educational goals. The head teacher is entrusted with both management and leadership roles. To build sustainable school community the secondary school teachers cannot be managers without being good leaders or being good teachers without being good managers, (Jocabus, 2005). Davies \& Davies (2010) further contend that the school leadership should reflect and develop mental images of where the school aspires to go. The current study investigated the effect of which school leadership on effective implementation of institutional strategic planning in public secondary schools in Eldoret West Sub-County, Uasin-Gishu county, Kenya.

\section{Methodology:-}

The current study adopted a descriptive survey design. Kombo and Tromp (2009) points out that a descriptive survey design enables the investigator to describe the state of activities as they are and report the findings accordingly. Further, Kothari (2009), notes that such design is efficient strategy of collecting descriptive data concerning the characteristics of populations to justify current conditions and practices. Moreover, descriptive surveys allow rapid collection of data from a large sample within the shortest time possible by use of questionnaires, interview schedules and document analysis. Mixed method research is a strategy to inquiry that combines both qualitative and quantitative forms of data collection and analysis. It involves the integration of theoretical assumptions, the use of both quantitative and qualitative approaches and the mixing of both approaches in a study. It is thus more than simply collecting and analyzing both kinds of data; it also involves the use of both approaches in tandem so that the overall strength of a study is greater than either one of the two approaches (Creswell, 2009). 
There are 53 public secondary schools in the sub-county therefore the study targeted 53 principals and 724 teachers. The principals and the teachers were targeted due to the fact that they are involved in the process of strategic plan implementation in secondary schools and therefore clearly understand the process. This research was based on a sample size determination formula advanced by Krejcie and Morgan (1970) as cited by Kasomo (2001). The formula is given as:

$\mathrm{n}=\frac{X^{2} * N * P(1-P)}{\left(M E^{2} *(N-1)\right)+\left(X^{2} * P *(1-P)\right)}$

Where:

$\mathrm{n}=$ Sample size

$\mathrm{X}^{2}=$ Chi-square for the specified confidence level at 1 degree of freedom

$\mathrm{N}=$ population size

$\mathrm{P}=$ population proportion

$\mathrm{ME}=$ Desired Margin of Error (expressed as a proportion)

In this case, the sample size for teachers was;

$=3.841 \times 724 \times 0.5(1-0.5) / 0.05 \times 0.05(724-1)+3.841 \times 0.5(1-0.5)$

$=695.221 / 2.51775$

$=276$

However, $30 \%$ of the secondary school principals was selected to participate in the study giving a total of 16 principals. The choice of 30\% was based on Mugenda and Mugenda (2003) Recommendations.

This study employed various sampling procedures which ensured a representative population and would allow for the generalization of the study findings to a larger population since it is not likely to seek the opinions and views of everyone in a population for generalization of the study findings. The sampling procedures which were used in this research included, stratified, simple random sampling and purposive sampling techniques. In selecting secondary schools which were included in this research, stratification was used to place schools in their quotas; Extra-County ( 2 schools), County (6 schools) and Sub-County schools ( 45 schools) totaling to 53 secondary schools. Stratification guaranteed that each individual stratum was assigned the proportionate number of secondary schools as in the population. Vogt, Gardner and Haeffele (2012) state that stratified sampling is used when the researcher wants to highlight specific subgroups within the population and this was appropriate for the study. In addition, simple random sampling technique was used to select teachers who participated in the study while purposive sampling was used to select Principals from each of the selected secondary schools. This research adopted both quantitative and qualitative data collection procedures where questionnaires were used to collect quantitative data while interviews were used to collect qualitative information.

To test the validity of the research instruments used in the study, the questionnaire was availed to thesis supervisors together with a panel of experienced scholars of Moi University to review the instruments. The outcomes obtained from piloting together with the comments from the supervisors were integrated in the final instrument revisions to enhance its validity. To determine reliability of research instruments, the researcher administered and readministered the same test two weeks after the first administration in a pilot study that was conducted with 30 teachers from the neghbouring Eldoret East Sub-County. Cronbach Alpha Coefficient was used to test on the reliability of the research instruments. A correlation coefficient of equal or more than 0.70 was considered adequate to allow the researcher proceed with the study as per the recommendations of Creswell (2009). In this study, a correlation coefficient of 0.79 was obtained on teachers' questionnaire which was acceptable.

The quantitative data from the questionnaire was first subjected to preliminary processing through validation, coding and tabulation in readiness for analysis with the help of the Statistical Package for Social Science (SPSS) computer package. Frequencies, percentages, means and Standard deviation was used to analyze quantitative data. Data analysed was presented by use of tables and figures. Pearson Correlation Analysis was employed to determine relationship that exists between the independent and dependent variables. Qualitative data from interview schedules was thematically classified and arranged before they were reported in narrations and quotations as per the research objectives. 


\section{Results and Discussions:-}

The aim of this study was to the relationship between principals' leadership and implementation of institutional strategic planning in public secondary schools. To realize this objective, the participants were requested to rank their degree of agreement on a five-point Likert scale items. The outcomes of information analyzed are shown in Table 1. Table 1:-Teachers' Responses on the Extent to Which Leadership, Influence Effective Implementation of Institutional Strategic Planning

\begin{tabular}{|l|c|c|c|c|c|c|c|c|c|c|}
\hline \multirow{2}{*}{ Statement } & \multicolumn{2}{|c|}{ SD } & \multicolumn{2}{c|}{ D } & \multicolumn{2}{c|}{ UD } & \multicolumn{2}{c|}{ A } & \multicolumn{2}{c|}{ SA } \\
\cline { 2 - 10 } & $\mathrm{F}$ & $\%$ & $\mathrm{~F}$ & $\%$ & $\mathrm{~F}$ & $\%$ & $\mathrm{~F}$ & $\%$ & $\mathrm{~F}$ & $\%$ \\
\hline $\begin{array}{l}\text { Leadership qualities affect } \\
\text { implementation of institutional } \\
\text { strategic plan }\end{array}$ & 26 & 11.0 & 17 & 7.2 & 20 & 8.4 & 123 & 51.9 & 51 & 21.5 \\
\hline $\begin{array}{l}\text { Style of leadership affects } \\
\text { implementation of strategic plan }\end{array}$ & 21 & 8.9 & 35 & 14.8 & 38 & 16.0 & 52 & 21.9 & 91 & 38.4 \\
\hline $\begin{array}{l}\text { The B.O.M is qualified and } \\
\text { experienced in academic } \\
\text { matters }\end{array}$ & 19 & 8.0 & 47 & 19.8 & 18 & 7.6 & 89 & 37.6 & 64 & 27.0 \\
\hline $\begin{array}{l}\text { Money accrued to the school is } \\
\text { properly discussed in B.O.M } \\
\text { meetings }\end{array}$ & 13 & 5.5 & 2 & .8 & 20 & 8.4 & 111 & 46.8 & 91 & 38.4 \\
\hline $\begin{array}{l}\text { Projects are properly planned } \\
\text { for during B.O.M meetings as } \\
\text { per the needs }\end{array}$ & 3 & 1.3 & 35 & 14.8 & 13 & 5.5 & 78 & 32.9 & 108 & 45.6 \\
\hline $\begin{array}{l}\text { The Secretary of the B.O.M } \\
\text { makes detailed reports during } \\
\text { meetings }\end{array}$ & 28 & 11.8 & 26 & 11.0 & 21 & 8.9 & 78 & 32.9 & 84 & 35.4 \\
\hline $\begin{array}{l}\text { The B.O.M have put in place } \\
\text { mechanisms of project } \\
\text { implementation }\end{array}$ & 25 & 10.5 & 65 & 27.4 & 21 & 8.9 & 74 & 31.2 & 52 & 21.9 \\
\hline $\begin{array}{l}\text { Division of labour is clearly } \\
\text { indicated during project } \\
\text { implementation }\end{array}$ & 0 & 0.0 & 37 & 15.6 & 10 & 4.2 & 65 & 27.4 & 125 & 52.7 \\
\hline
\end{tabular}

Table 1 shows that $123(51.9 \%)$ respondents agreed with the statement that leadership qualities affect implementation of institutional strategic plans, 51(21.5\%) teachers strongly agreed with the statement, 26(11.0\%) teachers strongly disagreed with the statement and 20(8.4\%) teachers were undecided while 17(7.2\%) teachers disagreed with the statement. The study findings showed that majority $(73.4 \%)$ of the teachers in secondary schools in Eldoret West Sub-County believed that leadership qualities affected the implementation of strategic plans. This implies that leaders with competencies such as Idealized characteristics, Inspirational Motivation, Intellectual Stimulation and Individualized Consideration have the ability to influence positively the implementation of strategic plans in their schools. Further Hall, Johnson, Wysocki \& Kepner (2002); Lussier \& Achua (2004); Stone, Russell \& Patterson (2003) amongst other researchers enumerates that among the competencies of required by leaders for effective strategic plan implementation are clear sense of purpose, value driven, strong role model, high expectations, persistent, self-knowing, perpetual desire for learning, love work and life-long learners. This therefore shows that there are certain qualities required by secondary school principals which enhance efficiency in strategic plan implementation.

Further, 91(38.4\%) teachers strongly agreed with the statement that style of leadership affects implementation of strategic plan, 52(21.9\%) teachers agreed with the statement, 38(16.0\%) teachers were undecided on the statement and 35(14.8\%) teachers disagreed with the statement while 21(8.9\%) teachers strongly disagreed with the statement. As shown by the responses, it emerged that majority (60.3\%) of the secondary school teachers in the region were of the view that style of leadership affected the implementation of strategic plans in secondary schools. Schools need transformational leaders who have the ability to enhance effective implementation of strategic plans. This is consistent with the works of Eshraghi, Harati, Ebrahimi \& Nasiri (2011) found out a significant positive relationship between the transformational style of leadership and leadership outcomes. Moreover, the researchers observed a significant relationship between the indices of transformational leadership namely idealized influence, inspirational 
motivation, intellectual stimulation and individualized consideration and the components of leadership outcomes namely extra effort, satisfaction, and effectiveness. This implies that efficiency in the implementation of strategic plans in public secondary schools is positively influenced by principals who are transformational in nature.

In addition, 89(37.6\%) teachers agreed with the statement that their BOM was qualified and experienced in academic matters, $64(27.0 \%)$ teachers strongly agreed with the statement, $47(19.8 \%)$ teachers disagreed with the statement and $19(8.0 \%)$ teachers strongly disagreed with the statement while 18(7.6\%) teachers were undecided on the statement. The responses showed that majority (64.6\%) of the teachers in public secondary schools in Eldoret West Sub-County reported that their BOM were qualified and experienced in academic matters. This shows that the $\mathrm{BOM}$ as a senior management organ in schools can positively influence academic achievement in schools which is one of the missions of schools. This is consistent with the findings of Thompson, Strickland and Gamble (2005) who found in their study that senior management's beliefs, values and assumptions are important to the overall success of their envisaged agenda. The role of leadership in management is largely determined by the culture of the school. This shows that school leadership is focused on senior management.

Similarly, 111(46.8\%) teachers agreed with the statement that money accrued to the school is properly discussed in B.O.M meetings, $91(38.4 \%)$ teachers strongly agreed with the statement, 20(8.4\%) teachers were undecided while $15(6.3 \%)$ teachers were in disagreement with the statement. From the responses, it emerged that majority (85.2\%) of the respondents believed that the BOM properly discuses money accrued to their schools during the BOM meetings. This implies that the BOM are open in discussing issues affecting the schools particularly financial issues. This was found to support Horton et al., (2005) who noted that openness is one of the leadership competencies required in the development and implementation of an effective succession planning strategy.

Moreover, 108(45.6\%) teachers strongly agreed with the statement that projects in their schools are properly planned for during B.O.M meetings as per the needs, $78(32.9 \%)$ teachers agreed with the statement and $38(16.1 \%)$ teachers were in disagreement with the statement while $13(5.5 \%)$ teachers were undecided on the statement. As shown by the responses, it emerged that majority $(78.5 \%)$ of the secondary school teachers were of the view that school projects were planned for by the School Board of management in accordance with the school needs. This shows that there was prioritization of certain projects by the BOM as per the needs of the students, teachers and the community. This is in line with the arguments of Gutsche (2009) who noted that a coherent overall plan that aligns with the organization goals and community needs will help the organization provide successful programs and services. This study finding therefore shows that prioritization of projects will help in achievement of the overall goal of the school.

Similarly, 84(35.4\%) teachers strongly agreed with the statement that the Secretary of the B.O.M makes detailed reports during meetings, 78(32.9\%) teachers agreed with the statement, 28(11.85) teachers strongly disagreed with the statement and 26(11.05) teachers disagreed with the statement while 21(8.9\%) teachers were undecided on the statement. The study findings suggested that majority (68.3\%) of the secondary school teachers in the study area reported that their BOM secretaries made detailed reports during meetings. This shows that the BOM secretaries were able to present and communicate to other members on the needs of the schools. This is an indication that the principals had the requisite competencies that enables efficiency in planning and implementation. This supports the work of Thomson et al., (2005) who pointed out that it is important to effectively communicate the vision as the strategic soundness of the journey for which management has opted. This therefore shows that the principals need to communicate to the BOM the vision of the school and the strategies they have laid in the achievement of this vision.

Moreover, 74(31.2\%) teachers agreed with the statement that the B.O.M have put in place mechanisms of project implementation, 65(27.4\%) teachers disagreed with the statement, 52(21.9\%) teachers strongly agreed with the statement and $25(10.5 \%)$ teachers strongly disagreed with the statement while $21(8.9 \%)$ teachers were undecided on the statement. The responses clearly points out that majority (53.1\%) of the teachers in public secondary schools in the study area noted that their BOM had put in place mechanisms for implementing school projects. This implies that there were strategies put in place to ensure completion of projects in schools. The central role of planning is the projection of targets looking and thinking forward in time (Efendioglo \& Karabulut, 2010). Therefore, planning helps in completion of stalled projects in schools and starting of other new projects. This is the central role of the school management particularly the PTA and the BOM.

In addition, 125(52.7\%) teachers strongly agreed with the statement that division of labour was clearly indicated during project implementation, 65(27.4\%) teachers agreed with the statement and 37(15.6\%) teachers were in 
disagreement with the statement while 10(4.2\%) teachers were undecided on the statement. It seems therefore that majority $(80.1 \%)$ of the teachers in public secondary schools in the study area believed that there was division of labour during project implementation in their schools. This implies that each team in schools are assigned various roles during project implementation so as to ensure their completion and achievement of set goals in in infrastructure development.

Interviews with the principals pointed out that as school leaders and secretary to the BOM they had laid down achievement of various sectors in the school. They pointed out that as principals they have to be involved in setting up of academic goals, infrastructure development and recruitment of teachers and non-teaching staff in cases of inadequacies amongst other duties. This clearly points out that the principals need to have certain competencies in order to ensure that the set goals are achieved.

The hypothesis of this study stated that:

$\mathrm{HO}_{1}$ : There is no statistically significant relationship between leadership and implementation of institutional strategic planning in public secondary schools. Pearson Correlation Coefficient (simply r) was used to establish the potential relationship between leadership and strategic plan implementation. The results of the analyzed information are presented in Table. 2 .

Table 2:-The Correlation Coefficient between Leadership and Strategic Plan Implementation

\begin{tabular}{|l|c|}
\hline Variables & Pearson Correlation Coefficient \\
\hline Leadership & $\mathrm{r}=0.559^{* *}$ \\
\hline Strategic Plan Implementation & \\
\hline $\mathrm{P}<0.01 ; \mathrm{N}=\mathbf{2 3 7}$ & \\
\hline
\end{tabular}

The results of Pearson Correlation Coefficient used for data analysis as shown in Table 2 suggested that there is a significant positive relationship between leadership and implementation of strategic plans in secondary schools at $\mathrm{p} \leq$ 0.01 significance level ( $\mathrm{r}=0.559)$. This is consistent with the results of Eshraghi, et al., (2011), Bliss (2005) and Caruso et al., (2002) who noted that change and transformation in leadership is highly recommended for bringing about changes in structure, culture, processes and other dimensions of schools. This implies that having transformational leaders in secondary schools including the principals, BOM members and PTA members could result in efficiency in achieving set goals impeded in the schools' strategic plans.

\section{Conclusions And Recommendations Of The Study:-}

Based on objective of this study, it was concluded that there was a significant positive relationship between leadership and implementation of strategic plans in secondary schools. This showed that improved leadership in secondary schools leads to an effective implementation of strategic plans. It was therefore recommended that there is need for secondary school leadership to have the competencies required for effective implementation of strategic plans. These competencies include idealized characteristics, inspirational motivation, intellectual stimulation and individualized consideration.

\section{References:-}

1. Allio, M.K. (2005). A short, practical guide to implementing strategy. Journal of business strategy, 26, 12-21.

2. Babie, E., \& Halley, F. (2007). Adventures in social research data analysis using SPSS 14.0 and 16.0 for Windows. (6th Ed.). New York, NY: Pine Forge Press Publishers.

3. Barnat, R. (2014). Strategic Management: Formulation and Implementation. Retrieved from http://www.introduction-to-management.24xls.com/ (Accessed 15/08/2016).

4. Bliss, S. (2005). The effect of emotional intelligence on a modern organizational leaders' ability to make effective decisions. Bellevue University. Cited from the World Wide Web, http://www.eqi.org.

5. Caruso, D.R., J.D. Mayer, \& P. Salovey. (2002). Emotional intelligence and emotional leadership. Mahwah, NJ: Erlbaum.

6. Creswell, J. W., \& Plano C. V. L. (2010). Designing and Conducting Mixed Methods Research. (2nd Ed.). London: Sage Publishers.

7. Davies, B. \& Davies, B.J. (2010), The Nature and Dimensions of Strategic Leadership, International Studies in Educational Administration 38(1): 5-21.

8. Davies, B. (2005). The Essentials of School Leadership (London: Paul Chapman Publishing and Corwin Press). 
9. Eacott, S. (2011). New Look Leaders or a New Look at Leadership? International Journal of Educational Management 25(2): $134-143$.

10. Efendioglu, A. M., \& Karabulut, A. T. (2010). Impact of strategic planning on financial performance of companies in Turkey. International Journal of Business and Management, 5(4), 3-12.

11. Eshraghi, H., Harati, S. H., Ebrahimi, K. \& Nasiri, M. (2011). A Study of the relationship between transformational leadership and leadership outcomes in the managers of physical education offices in Isfahan Province. Australian Journal of Basic and Applied Sciences, 5(12): 2544-2548.

12. Fullan, M. (2004), Leadership and Sustainability: System Thinkers in Action (Thousand Oaks, CA: Sage Publications).

13. Graetz, F. (2010). Strategic change leadership. Management Decision, 8(38), 550-562.

14. Jacabus, A. S. (2005). Changing role of secondary school principal in building sustainable communities. Journal of Management. 34-27.

15. Jasparro, R.J. (2006), Strategic Planning: Is it Worth the Effort? The Superintendent's Perspective, E-Journal of Organizational Learning and Leadership: February.

16. Kasomo, D. (2001). Research Methods in Humanities and Education. Njoro, Egerton University Press.

17. Kothari, C. R., (2008). Research Methodology: Methods and Techniques (2 ${ }^{\text {nd }}$ Ed).Age, New Delhi, International publishers.

18. Krejcie, R. V, \& Morgan, D. W. (1970). Determining sample size for Research Activities. Educational \& Psychological measurement,30, (1) 607-610).

19. Leithwood, K. \& Jantzi, D. (2005), Transformational Leadership in a School Context, in B. Davies (ed.), The Essentials of School Leadership. (London: Paul Chapman).

20. Njeru, N. E, \& Stephen, M. M. A \& Wanbui, M.A. (2013). Analysis of factors influencing formulation of strategic plans in Embu North sub county, Kenya. Global business and economics research journal, 2(5)- 116129.

21. Quong, T. \& Walker, A. (2010), Seven Principles of Strategic Leadership, International Studies in Education Administration 38(1): 22-34.

22. Ralph, J. J. (2008). Should school superintendents use the process of strategic planning to lead school improvement and change initiatives? Strategic Planning: Is It Worth the Effort? www.leadingtoday.org/../feb06rjj.htm. Retrieved $13^{\text {th }}$ January, 2018.

23. Shivachi, N.H. (2007). The Impact of Kenya Institute in -service Training Programmes on Public Secondary Schools Management in Lugari District, Kenya. KU unpublished MED thesis.

24. Song, M., Im, S., Bij, H., \& Song, L. Z. (2011). Does Strategic Planning Enhance or Impede Innovation and Firm Performance? Journal of Product Innovation Management, 28(4), 503-520.

25. Steven, H. (2008). Secondary School Strategic Planning. Turkana Headteachers Conference April 2008.

26. Steyn, H. \& Wolhuter, C. (2010), Creating Sustainable Learning Environment of Schools by means of Strategic Planning: The Experience of Engagement by Comparative Education Team at University, South African Journal of Higher Education 24(3): 56-70.

27. Thompson, A. A., Strickland, A. J., \& Gamble, J. E. (2005). Crafting and executing strategy: The quest for competitive advantage w/OLC/Premium Content Card ( $14^{\text {th }}$ Ed.). New York: McGraw-Hill/Irwin.

28. UNESCO, (2010), Strategic Planning: Organizational Arrangement, Educational Sector Working Paper 2, International Institute for Educational Planning, Paris.

29. Vogt, W. P., Gardner, D. C., \& Haeffele, L. M. (2012). When to Use What Research Design. New York, NY: Guilford Press.

30. Xaba, M. (2006), The Difficult of School Development Planning, South African Journal of Education 26(1): $15-26$. 